\title{
Liber homo suo nomine utilem Aquiliae habet actionem: D. $9,2,13$ pr. in context
}

\section{Introduction}

I first met Boudewijn shortly after he had been appointed Regius Professor in late 2005. But it was only in Michaelmas Term of the next year that we began to teach together on the advanced Roman Law Delict course at Oxford. Initially he taught the section of the course devoted to the lex Aquilia and left the easier portions on furtum and iniuria to me. Later, I began to teach some seminars on the lex Aquilia too. What strikes me now, looking back now from a distance of almost eight years, is Boudewijn's generosity to a younger and less experienced colleague. Not only did he allow me to teach more-or-less whatever I wanted from the syllabus; he was also unfailingly attentive and enthusiastic about what I had to say. Even rather speculative ideas were given fair hearing and invariably attracted a learned and lively response. I hope the students to whom the seminars were delivered enjoyed them as much as I have.

In fact, the subject of this piece was suggested to me during a Roman Law Delict seminar which I delivered recently at Boudewijn's invitation in the Old Library at All Souls, on the subject of the identity of claimant and defendant in the context of the lex Aquilia. During the course of the seminar we discussed the issues surrounding injuries to free persons, and in particular the texts on this subject preserved at D. 9,2,5,3-7 pr., D. 9,2,7,4 and D. 9,2,13 pr. I happened to mention the point that D 9.2.13 pr., which appears to grant to a free man an actio utilis in respect of his own injuries even in classical law, may originally have referred only to a much narrower case, the liber homo bona fide serviens. This gave rise to a lively class discussion, and Boudewijn and I subsequently exchanged several emails on the subject. But some while later I found myself wondering how that reading of the text might be influenced by a closer consideration of its original context in Book 18 of Ulpian's edictal commentary. The paper which follows is my attempt to work through that line of thought. I hope it is a fitting tribute to Boudewijn. 


\section{The context:Ulpian's commentary on erus}

According to Digest 9,2,2 pr. (Gaius 7 on the provincial edict), the first chapter of the lex Aquilia provided as follows:

Lege Aquilia capite primo cavetur: "ut qui servum servamve alienum alienamve quadrupedem vel pecudem iniuria occiderit, quanti id in eo anno plurimi fuit, tantum aes dare domino damnas esto." ${ }^{1}$

Modern reconstructions differ slightly from this version. Most recently, John Crook has advanced the following conjecture:

si quis servum servam alienum alienam quadrupedem iniuria occiderit, quanti id in eo anno plurimi fuit, tantum aes ero dare damnas esto ${ }^{2}$.

Similarly, while the version of the third chapter of the lex preserved in Digest 9,2,27,5 (from Ulpian 18 on the edict) is this -

Ceterarum rerum praeter hominem et pecudem occisos si quis alteri damnum faxit, quod usserit fregerit ruperit iniuria, quanti ea res erit in diebus triginta proximis, tantum aes domino dare damnas esto ${ }^{3}$.

- Crook reconstructs the original wording of the text as follows:

si quis alteri damnum faxit, quod usserit fregerit ruperit iniuria, quanti ea res fuit in diebus triginta proximis, tantum aes ero dare damnas esto ${ }^{4}$.

It is not necessary here to evaluate the accuracy of these reconstructions. I wish to emphasise one point only, that it is clear that both chapters of the lex allocated the actio legis Aquiliae specifically to the owner of the thing damaged. Only the terminology is unstable: whereas the quotations from the lex given in the Digest itself refer to the dominus, Crook, like Bruns before him $^{5}$, prefers the archaic erus ${ }^{6}$. The emendation is hardly controversial. That it was erus rather than dominus that appeared in the original text appears from a comment made by

1 Iwould like to thank Robin Evans-Jones and Stephen Wagener for their helpful comments on a draft of this article. Latin texts throughout are taken from $T$. Mommsen/P. Krueger, The Digest of Justinian, English translation edited by Alan Watson, Philadelphia 1985. Watson's translation of this passage, somewhat adapted, is, "Who kills unlawfully a slave or slave-girl belonging to someone else or a four-footed animal of the class of cattle, let him be condemned to pay the owner the highest value that the property had attained in the previous year".

2 J.A. Crook, in: M.H. Crawford (ed.), Roman statutes, ii, London 1996, 725.

3 Watson's translation of this passage, again somewhat adapted, is, "In the case of all other things apart from slaves or cattle that have been killed, if anyone does damage to another by wrongfully burning, breaking, or spoiling, let him be condemned to pay to the owner whatever the matter shall be worth in the next thirty days."

4 Crook (Fn. 2) 725.

5 C.G. Bruns, Fontes iuris Romani antiqui, 5th ed. by Th. Mommsen, Freiburg 1887, 43.

6 Cf. J.A. Crook in Crawford (Fn. 2) 726. 


\section{FINAL PRE-PUBLICATION VERSION June 2014}

\section{Ulpian himself in D. 9,2,11,6: Legis autem Aquiliae actio ero competit, hoc est}

domino ${ }^{7}$.

That leads to a second preliminary point. According to Otto Lenel's Palingenesia, in the texts now preserved as 9,2,11,6 - 10,13,15,17, 19, and 35 of Digest 9,2, all of which are drawn from Book 18 of Ulpian's lemmatic commentary on the praetor's edict, Ulpian was commenting on the word erus in the context of Chapter $I^{8}$. These texts read as follows:

D. 9,2,11,6. Legis autem Aquiliae actio ero competit, hoc est domino. 7. Si in eo homine, quem tibi redhibiturus essem, damnum iniuria datum esset, lulianus ait legis Aquiliae actionem mihi competere meque, cum coepero redhibere, tibi restituturum. 8 . Sed si servus bona fide alicui serviat, an ei competit Aquiliae actio? Et magis in factum actio erit danda. 9. Eum, cui vestimenta commodata sunt, non posse, si scissa fuerint, lege Aquilia agere lulianus ait, sed domino eam competere. 10. An fructuarius vel usuarius legis Aquiliae actionem haberet, lulianus tractat: et ego puto melius utile iudicium ex hac causa dandum.

h.t. 13 pr. Liber homo suo nomine utilem Aquiliae habet actionem: directam enim non habet, quoniam dominus membrorum suorum nemo videtur. Fugitivi autem nomine dominus habet. 1. Iulianus scribit, si homo liber bona fide mihi serviat, ipsum lege Aquilia mihi teneri. 2. Si servus hereditarius occidatur, quaeritur, quis Aquilia agat, cum dominus nullus sit huius servi. Et ait Celsus legem domino damna salva esse voluisse: dominus ergo hereditas habebitur. Quare adita hereditate heres poterit experiri. 3. Si servus legatus post aditam hereditatem sit occisus, competere legis Aquiliae actionem legatario, si non post mortem servi adgnovit legatum: quod si repudiavit, consequens esse ait lulianus dicere heredi competere.

h.t. 15 pr. Huic scripturae consequens est dicere, ut, si ante aditam hereditatem occidatur legatus servus, apud heredem remaneat Aquiliae actio per hereditatem adquisita. Quod si vulneratus sit ante aditam hereditatem, in hereditate quidem actio remansit, sed cedere ea legatario heredem oportet. 1. Si servus vulneratus mortifere postea ruina vel naufragio vel alio ictu maturius perierit, de occiso agi non posse, sed quasi de vulnerato, sed si manumissus vel alienatus ex vulnere periit, quasi de occiso agi posse lulianus ait. Haec ita tam varie, quia verum est eum a te occisum tunc cum vulnerabas, quod mortuo eo demum apparuit: at in superiore non est passa ruina apparere an sit occisus. Sed si vulneratum mortifere liberum et heredem esse iusseris, deinde decesserit, heredem eius agere Aquilia non posse...

h.t. 17. Si dominus servum suum occiderit, bonae fidei possessori vel ei qui pignori accepit in factum actione tenebitur.

h.t. 19. Sed si communem servum occiderit quis, Aquilia teneri eum Celsus ait: idemest et sivulneraverit

h.t. 35. ... quia retro adcrevisse dominium ei videtur.

7 "The action on the lex Aquilia is available to the erus, that is, the owner [dominus]".

8 O. Lenel, Palingenesia iuris civilis, ii, Leipzig 1889 (reprinted 1960), $524-525$. 


\section{FINAL PRE-PUBLICATION VERSION June 2014}

In fact, under this rubric, as is obvious from the texts set out above, Ulpian discussed not only Chapter I cases of killing but also cases that should logically have been dealt with in the context of Chapter III (cases involving the wounding of slaves and damage to inanimate objects). Indeed, he seems to have started with the Chapter III cases $(11,6-10,13$ pr.-1) and moved on to Chapter I only at 13,2. Thus he disposed of the issue of who could sue under the lex in the context of his commentary on Chapter I; there is no further treatment of this issue specifically in the context of Chapter III $^{9}$.

Ulpian discussed in order the following problems: in 11,7, the case where a defective slave who is shortly to be returned to his original seller is injured (Julian's answer: an action on the lex Aquilia accrues to the purchaser as owner, but he must cede the action to the seller when ownership is restored to him); in 11,8, the case where the injured slave was serving in good faith one who is in fact not his owner (Ulpian's answer: the putative owner has an actio in factum in respect of the slave's injuries); in 11,9 , the case where clothes which have been lent are torn, i. e. by a third party (Julian's answer: the borrower has no actio legis Aquiliae; that action remains with the owner); in 11,10 the case where property held by a usufructuary is damaged (Julian considered the possibility that perhaps an actio legis Aquiliae might be available to the usufructuary, but Ulpian thought that only an actio utilis should be granted). After that comes $13 \mathrm{pr}$. itself, which will be dealt with in the next section together with 13,1 .

As for the remainder of Ulpian's commentary, 13,2 - 3 and 15 deal with questions regarding action by heirs and legatees in respect of slaves killed or wounded. Regarding in particular the case where a slave who forms part of an inheritance has been killed before the inheritance is claimed, Ulpian says, "it is debated who can bring the Aquilian action, since no-one is the owner [dominus] of such a slave. Celsus says that the law meant any loss [damnum] to be made good to the owner: therefore the inheritance is deemed to be the owner. Accordingly, the heir may sue when he has entered into the inheritance." $(13,2)$ The same is true of the case where a slave left as a legacy is killed before the heir enters on the inheritance, i. e. the Aquilian action acquired by the inheritance remains for the heir. (15 pr.) "But if the slave should be wounded before the entry of the heir, the action still remains in the inheritance, but it should be ceded to the legatee by the heir." (15 pr. continued). As for the cases discussed in 15,1, where a mortally wounded slave dies only after he has been freed or alienated (by the tetstator), both Julian and Ulpian thought that the slave heir should generally

9 Cf.A. Rodger, The palingenesia ofthe commentaries relatingtothe lexAquilia, SZ124 (2007) $145,153$. 


\section{FINAL PRE-PUBLICATION VERSION June 2014}

have an action for killing. Their reasons for taking this view seem to had to do with the nature of the Chapter I delict itself ${ }^{10}$.

In 17 Ulpian says that a master who kills his own slave is liable in factum to the slave's bona fide possessor, or to a creditor to whom he has pledged the slave. In 19, continuing the theme, he says that Celsus claims that if someone kills a slave owned jointly with another, the lex Aquilia applies, and it is the same if he wounds him. Finally, the brief fragment in 35 has been edited so that it follows on directly from the fragment of Marcellus 21 digesta which immediately precedes it in the context of 9,2. D. 9,2,34 deals with actions arising where a slave who is the subject of a joint legacy is killed when only one legatee had claimed the legacy (the other subsequently renounced it). Ulpian seems to say (in 35) that the legatee who claimed the legacy can proceed as if he were the sole legatee, "because ownership is deemed to have accrued to him retrospectively".

The criterion employed by Ulpian in his commentary on the word erus does not appear to be who among the potential claimants had suffered loss as a result of the slave's injury, as might be thought to be the case in the modern English tort of negligence, for example ${ }^{11}$. Admittedly this criterion does seem to be employed by Celsus (as reported by Ulpian) in 13,2, and is clearly employed by Paul in 30,1 (22 on the edict). And it is at least a question whether it is in fact the basis for Ulpian's the distinction between the case where a slave left as a legacy is killed before the heir enters on the inheritance (the heir has the action) and the case where such a slave is merely wounded, in which case the heir is to cede his action to the legatee. But generally speaking, questions of loss and the calculation of damages are postponed for treatment later, in Ulpian's lemmatic commentary on the words quanti is homo in eo anno plurimi fuisset (or quanti id in eo anno plurimi fuit) in the context of Chapter I, and more generally in Chapter $\mathrm{III}^{12}$. In his commentary on erus, Ulpian appears to have been concerned with the incremental expansion of the owner category to include persons closely analogous to owners, whether usufructuaries, bona fide possessors, pledgees or co-owners (in 11,6-10,17, 19), and persons (e. g. heirs) to whom an owner's cause of action accrued $(11,7,13,2,15,35)^{13}$. In Ulpian's eyes, this seems to be an exercise in

10 For a detailed account of the first case discussed in 15,1, see H. Scott, Killing and causing death in Roman law, Law Quarterly Review 129 (2013) 101. Cf. D. 9,2,21,1 (Ulpian.18ed.);D. 9,2,51 pr. (Julian. 86 dig.).

11 For general comparison between Roman law and modern European legal systems in this respect see F.H Lawson, Negligence in the civil law, Oxford 1955, 67

12The structure of Ulpian's commentary on Chapter III is difficult to pin down. Lenel himself thought that in $27,25-35$ and 29 pr.-4, Ulpian was commenting on the words damnum faxit

... iniuria: Lenel (Fn. 8) 530 - 531. But see now Rodger (Fn. 9) 148 n. 19 and $176-189$. Loss questions appear to feature prominently in D. 9,2,27,17- 21 . 


\section{FINAL PRE-PUBLICATION VERSION June 2014}

13 Cf. J. Thomson, Who could sue on the lex Aquilia?, Law Quarterly Review 91 (1975) 208. 


\section{FINAL PRE-PUBLICATION VERSION June 2014}

statutory interpretation: how was the word erus in the context of Chapters I and III to be construed?

\section{Digest 9,2,13 pr.}

Now, finally, we are in a position to consider $13 \mathrm{pr} .-1$. Again, this reads as follows:

Liber homo suo nomine utilem Aquiliae habet actionem: directam enim non habet, quoniam dominus membrorum suorum nemo videtur. Fugitivi autem nomine dominus habet. 1. Iulianus scribit, si homo liber bona fide mihi serviat, ipsum lege Aquilia mihi teneri.

This short fragment generates considerable difficulty. First, it is difficult to follow Ulpian's train of thought here. The three main propositions advanced in the first and second sentences of $13 \mathrm{pr}$. (A free man has on his own account an actio utilis modelled on the Aquilian action; an owner has an action on account of a runaway slave) and in 13,1 (if a free man serves in the honest belief that he is my slave, he is liable to me under the lex Aquilia) do not appear to have any obvious connection to one another. Nor do they appear to have any obvious bearing onthe subject in hand. Starting with the second proposition, it is entirely uncontroversial that an owner should be able to sue in respect of injury to a fugitive slave: this case falls within the basic rule $(11,6)$ with which Ulpian's treatment began. Regarding the third proposition, this seems to concern Passivlegitimation rather than Aktivlegitimation: that is, a party's capacity to be sued rather than to sue. Arguably that question might well be thought to have some link to the issue under discussion, i. e. the meaning of erus. But it appears to arise rather abruptly in the context.

As for $13 \mathrm{pr}$. itself - "A free man has on his own account [suo nomine] an actio utilis modelled on the Aquilian action: he cannot have the direct action under the lex because no one appears to be the owner [dominus] of his own limbs" - this text appears to give an action (albeit an actio utilis only) to a free man sui iuris in respect of his own injury. Thus it constitutes the basis for the extension of the lex Aquilia to include injuries to free persons in the later (i. e. medieval and modern) civilian tradition ${ }^{14}$. In that, it seems to go further than any other text preserved in Digest 9.2. The closest we come to that position, apart from $D$ 9,2,13 pr. itself, is $D$ 9,2,5,3 and $7 \mathrm{pr}$. (comprising a continuous passage excerpted from Ulpian 18 on the edict), which deals with inadvertent injury to a free-born boy:

14 E.g. R. Zimmermann, The law of obligations: Roman foundations of the civilian tradition, Cape Town 1990, $1024-1026$ 


\section{FINAL PRE-PUBLICATION VERSION June 2014}

D. 9,2,5,3. Si magister in disciplina vulneraverit servum vel occiderit, an Aquilia ten- eatur, quasi damnum iniuria dederit? Et lulianus scribit Aquilia teneri eum, qui eluscaverat discipulum in disciplina: multo magis igitur in occiso idem erit dicendum. Proponitur autem apud eum species talis: sutor, inquit, puero discenti ingenuo filio familias, parum bene facienti quod demonstraverit, forma calcei cervicem percussit, ut oculus puero perfunderetur. Dicit igitur lulianus iniuriarum quidem actionem non competere, quia non faciendae iniuriae causa percusserit, sed monendi et docendi causa: an ex locato, dubitat, quia levis dumtaxat castigatio concessa est docenti: sed lege Aquilia posse agi non dubito.

[h.t. 6 (Paul 22 on the edict). Praeceptoris enim nimia saevitia culpae adsignatur.]

h.t. 7. Qua actione patrem consecuturum ait, quod minus ex operis filii sui propter vitiatum oculum sit habiturus, et impendia, quae pro eius curatione fecerit ${ }^{15}$.

Having described the incident itself in 5,3, and concluded that an action (on the lex Aquilia $^{16}$ ) can be brought against the defendant shoemaker, in 7 pr. Ulpian seems to say that in this case the father will recover the amount of his loss of prospective profit from his son's services, and also medical expenses. There is no claim for the diminution in his value: obviously, as a free person, he has none. This is made clear in D. 9,3,1,5 (Ulpian 23 on the edict), which deals with the edict de effusis vel deiectis:

Sed cum homo liber periit, damni aestimatio non fit in duplum, quia in homine libero nulla corporis aestimatio fieri potest ... ${ }^{17}$

Again, the proposition that a father could sue in respect of injuries to his free-born son is a more modest one than that apparently advanced in 13 pr. A child in his father's paternal power (a filiusfamilias) is analogous to a slave, given the degree of personal and economic control which a paterfamilias exercised over his child ${ }^{18}$. Indeed, it has been argued that Roman law did not originally distinguish between these different sovereignties, that is, an owner and a father were seen as powerful in very similar ways $^{19}$.

15 Cf. D. 19,2,13,4 (Ulpian. 32 ed.).

16 Wittmann believes this text to be interpolated, at least insofar as it appears to grant an actio directa: Wittmann (Fn. 20) 89. See also U. von Lübtow, Untersuchungen zur lex Aquilia de damno iniuria dato, Berlin 1970, 117-18, and the references cited there.

17 "When a free man is killed, there is no doubling of the assessment because in the case of a free man no assessment [aestimatio] of his body is possible ...".

18 E.g. W.W. Buckland, A text-book of Roman law from August to Justinian, 3rd ed. rev. P. Stein, Cambridge, 1963, 102-14.

19 See M. Kaser, Neue Studien zum altrömischen Eigentum, SZ 68 (1951) 131; M. Kaser, The concept of Roman ownership, Tydskrif vir Hedendaagse Romeins-Hollandse Reg 27 (1964) 5, 6-7; G. Diósdi, Ownership in ancient and preclassical Roman law, Budapest 1970, 53-56; P. Birks, The Roman concept of dominium and the idea of absolute 
FINAL PRE-PUBLICATION VERSION June 2014 ownership, Acta Juridica (1985) 1, 25-26. 


\section{FINAL PRE-PUBLICATION VERSION June 2014}

In fact, the weight of opinion favours the view that the first sentence of $13 \mathrm{pr}$. has been altered from its original Ulpianic form, whether at some point early in the post-classical period or by Justinian's compilers ${ }^{20}$. Regarding the nature of the interpolation, here there are two views. The predominant one is that the original text rejected the granting of Aquilian protection completely: originally it said that a free man has on his own account no actio utilis after the Aquilian action. The second half of the sentence, "he cannot have the direct action under the lex because no one seems to be the owner of his own limbs", is said to be a postclassical gloss ${ }^{21}$. On the other hand, Wittmann, developing an idea originally advanced by Kunkel, has argued that this fragment, like 13,1, originally referred to the liber homo bona fide serviens, at least insofar as it hasanauthentic core ${ }^{22}$.

\section{The liber homo bona fide serviens}

Who exactly was the liber homo bona fide serviens ${ }^{23}$ ? It is of course not difficult to imagine a situation where someone knows themselves himself to be free but is forced to act as a slave, whether by one aware of his true status or otherwise. Equally, we do have some idea why in the ancient Roman world someone might willingly become a liber homo mala fide serviens, a free man pretending to be a slave: he would pose as a slave and allow himself to be sold into slavery by a co-conspirator; the seller would then abscond, putting himself beyond the reach of any contractual action ${ }^{24}$, and a short while later the putative slave would be

20 The different views in this respect are summarised by $\mathrm{R}$. Wittmann, Die Körperverletzung an Freien im klassischen römischen Recht, Munich 1972, 76 - 77. See also von Lübtow (Fn. 16) 119-20, especially n. 166a.

21 Again, full references are collected by Wittmann (Fn. 20) 82.

22 P. Jors/W. Kunkel, Römisches Privatrecht, 3rd ed., Berlin 1949, 257 n. 9; Wittmann (Fn. 20) 75-82, 98-104. Feenstra agrees: R. Feenstra, L'application de la loi Aquilia en case d'homicide d'un homme libre, de l'epoque classique a celle de Justinien, in: J.A. Ankum et al. (eds.), Melanges Felix Wubbe, Fribourg 1993, 141, 147.

23 There is an extensive literature on the liber homo bona fide serviens: recent examples include

A. Söllner, in: J.M. Rainer (ed.), Corpus der römischen Rechtsquellen zur antiken Skla- verei, Teil IX: Irrtümlich als Sklaven gehaltene freie Menschen und Sklaven in unsicheren Eigentumsverhältnissen, Stuttgart 2000; J. Harke, Liber homo bona fide serviens und Vertragsgeltung im klassischen römischen Recht, RIDA 52 (2005) 163; E. Filippi, Liber homo bona fide serviens, in: E. Chevreau/D. Kremer/A. Laquerrière-Lacroix (eds.), Carmina luris: Melanges en I'honneur de Michel Humbert, Paris 2012, 297. Works of ap- parent relevance to this paper which I was unfortunately unable to consult include G. Valditara, Superamento dell'aestimatio rei nella valutazione del danno aquiliano ed estensione della tutela ai non domini, Milan 1992 (reviewed by B. Albanese, IURA XLIII [1992] 244) and the work by Söllner referred toabove. 


\section{FINAL PRE-PUBLICATION VERSION June 2014}

24 On the validity of such a sale see D. 18,1,70 (Licinnius Rufinus 8 reg.) and generally $R$. Evans- 


\section{FINAL PRE-PUBLICATION VERSION June 2014}

"recognised" by a friend (another co-conspirator) who would claim his liberty $^{25}$. The law's response was to enslave for real the one who had posed as a slave, at least where the putative owner had been in good faith and where the putative slave had shared in the price ${ }^{26}$. There is even discussion in the Digest of cases where both putative owner and putative slave knew the true position but elected to act as master and slave anyway. For example, the edict on tax farmers (discussed in Digest 39,4), which was designed to combat extortion by a tax farmer or his familia, is said by Ulpian to apply not only to the tax farmer's actual slaves but also to the slave of another serving him bona fide and indeed mala fide, "for often vagrant and fugitive slaves are even knowingly engaged by tax farmers in this kind of work, and therefore even if a free man acts as a slave, this edict applies." ${ }^{27}$

As for the liber homo bona fide serviens, the formulation liber homo qui bona fide servi strongly suggests that the bona fides in question was that of the liber homo himself ${ }^{28}$. However, it seems equally to have been required that his putative owner believed the liber homo to be his slave. The same reciprocity is evident in the related case of the servus qui aliquem bona fide servit, the slave who in good faith serves the wrong master, discussed in D. $9,2,11,8$. Again, the bona fides referred to in this stock phrase appears to be that of the slave, however implausible that might appear on a priori grounds $^{29}$. Yet the bona fides of his putative master is again clearly implied. Indeed, the putative master of another's slave is often referred to as his bona fide possessor, and it seems that the expressions bona fide possidere and bona fide servire are used interchangeably to describe the same case $\mathrm{e}^{30}$. Thus the bona fides in these cases - the liber homo bona fide serviens and servus qui aliquem bona fide servit - is perhaps best understood as reciprocal: The bona fide belief that the subject is in fact the slave of his putative master must be shared by both master and

Jones, The origins of Justinian's Institutes 3.23.5, Cambridge Law Journal 53 (1994) 473 and G. MacCormack and R. Evans-Jones, The sale of res extra commercium in Roman law, SZ 112 (1995)330.

25 See e. g. A. Watson, Roman slave law, Baltimore 1987, 9, and generally D. 40,12.

26 Watson (Fn. 25) 9, relying on D. 40,12,7,2 and 33 (buyer in good faith) and D. 40,13,1 pr. (putative slave sharing in the price).

27D. 39,4,12,2 (Ulpian. 38 ed.): Familiae autem appellatione hic servilem familiam contineri sciendum est. Sed et si bona fide publicano alienus servus servit, aeque continebitur, fortassis et mala fide; plerumque enim vagi servi et fugitivi in huiusmodi operis etiam a scientibus habentur. Ergo et si homo liber serviat, hoc Edictum locum habet.

28 E.g. D. 41,1,54 (Pomponius 31 Quint. Muc.); D. 45,1,118 (Papinian. 27 Quaest.); D. 47,10,15,48 (Ulpian. 57 ed.).

29 Cf. W.W. Buckland, The Roman law of slavery, Cambridge 1908, 331, especially n. 2.

30 Buckland (Fn. 29) 331, relying on C. Salkowski, Zur Lehre vom Sklavenerwerb, Leipzig 1891. 


\section{FINAL PRE-PUBLICATION VERSION June 2014}

servant; this shared belief in the apparent state of affairs is necessary to constitute the legal institution.

\section{Wittmann's analysis and reconstruction of the original text of $13 \mathrm{pr}$.}

Returning to 13 pr., Wittmann's arguments in favour of the view that it referred originally to the liber homo bona fide serviens are as follows. First, he relies on the phrase suo nomine ${ }^{31}$. The addition of this phrase would, he says, be unintelligible if the sentence referred to injury to a free person as such: to whom could the action accrue if not the free man himself? On the other hand, if indeed the text concerned the liber homo bona fide serviens, suo nomine makes good sense. It has a clarificatory function, in that it distinguishes the claim of the liber homo from that of his putative master. Here Wittmann refers inter alia to 4,4,6 in Justinian's Institutes in which the phrase suo nomine appears to perform a similar clarificatory role:

Sed si libero, qui tibi bona fide servit, iniuria facta sit, nulla tibi actio dabitur, sed suo nomine is experiri poterit: nisi in contumeliam tuam pulsatus sit, tunc enim competit et tibi iniuriarum actio ${ }^{32}$.

Furthermore, Wittmann points to the treatment of the liber homo bona fide serviens in 13,1, which immediately follows 13 pr. in Ulpian's analysis ${ }^{33}$. The fact that this text deals with the Passivlegitimation of the liber homo bona fide serviens - whether he could be sued under the lex Aquilia strongly suggests that Ulpian was dealing with Aktivlegitimation in respect of the same liber homo bona fide serviens in the immediately preceding 13 pr. Finally, Wittmann makes a still more persuasive argument, based on the wider context of 13 pr., namely Ulpian's discussion of Aktivlegitimation under the lex Aquilia $^{34}$. It appears initially that the general question of the claim of a free man on account of a bodily injury done to him could be assigned to this context. But on reflection this cannot be so, since in this general case any claimant other than the injured person himself is unimaginable. Thus if one were to interpret the first sentence of $13 \mathrm{pr}$. as concerning a free man as such, that sentence would be contextless. But as amended, it fits perfectly.

31 Wittmann (Fn. 20) 77.

32 "But if iniuria has been done to a free man who is bona fide serving you, no action is given to you, but he can sue in his own name [suo nomine], unless he has been beaten in order to insult you; for, then, the actio iniuriarum is available to you ...".

33 Wittmann (Fn. 20) 78.

34 Ibid. 


\section{FINAL PRE-PUBLICATION VERSION June 2014}

Wittmann's conclusion, therefore, is that the first part of the first sentence of 13 pr. originally contained an adjectival clause qualifying liber homo, something like qui bona fide nobis servit (cf. D. 41,1,54, Pomponius 31 on Quintus Mucius) or qui bona fide servit mihi (cf. D. 45,1,118, Papinian 27 Questions) $)^{35}$. He concludes that the goal of the liber homo's claim arising from the text thus reconstructed must have been the replacement of medical costs and lost earnings, as in the case of the filiusfamilas discussed by Ulpian in D. 9,2,5,3 and $7 \mathrm{pr}^{36}$. Thus the putative slave does not make the Aquilian claim in the full sense, for the objective diminution in his value, as his owner would have been entitled to do had he been in fact his slave. To take such diminution of value into account in the case of the liber homo bona fide serviens was impossible in light of the liberum corpus nullam recepit aestimationem rule $^{37}$.

VI. The importance of context: towards a better understanding of $13 \mathrm{pr}$.

Wittmann's reading of $13 \mathrm{pr}$. (namely, that it concerns the liber homo bona fide serviens in particular) is convincing, and I am in substantial agreement with it. However, I wish to propose a modification to his view, which rests on a more precise understanding of the context in which Ulpian was speaking. Although in the original $13 \mathrm{pr}$. Ulpian clearly did address the question whether the liber homo bona fide serviens had a claim in respect of his own injuries, Iwish to suggest that this question - the claim of the liber homo bona fide serviens - was not his primary focus. Rather, his starting point - both conceptually and in terms of the order in which he dealt with these propositions - was whether the bona fide possessor of such a liber homo bona fide serviens had himself a claim in respect of the liber homo's injuries.

Why do I say this? First, because in the context of Ulpian's commentary onthe word erus it is a question which obviously requires an answer. Reading 13 pr., we have just encountered the proposition (in 11,8) that if a servus qui bona fide alicui servit is injured, his putative master has an actio in factum in respect of his injuries. There is also $17 \mathrm{pr}$., occurring slightly later in Ulpian's commentary on erus, which gives the bona fide possessor of a slave an actio in factum against the master who kills him. We know from D. 41,1,54,4 that a liber homo bona fide

35 Wittmann (Fn. 20) $79-80$.

36 Wittmann (Fn. 20) $81-82$.

37 D. 9,3,1,5 (Ulpian. 23 ed.). Cf. section 3 above. 


\section{FINAL PRE-PUBLICATION VERSION June 2014}

serviens was himself possessed by his putative master ${ }^{38}$. Surely, then, it is at least a question whether such a bona fide possessor of a liber homo might not equally have an action in respect of his injuries?

However, I think that the answer to this question must have been $\mathrm{no}^{39}$. The reason for this was that the subordination of the liber homo to his putative dominus was purely factual in nature, arising as it did from their shared misapprehension as to his legal status ${ }^{40}$. Simply put, the liber homo was not a res susceptible to dominium, but a free person sui iuris ${ }^{41}$. Given that, he could have no erus, however widely that term was interpreted. This point appears trite: indeed, that may be the reason why the Compilers excised this initial sentence from Ulpian's analysis of the problem. But Ulpian may have had particular reason to make it. It was in fact correlative to his innovations in the context of the delict of iniuria, where he seemed to be the first to treat the actio iniuriarum as arising directly from assaults on slaves' personalities, rather than seeing slaves as mere vehicles via which iniuria could be perpetrated against their masters ${ }^{42}$. Since Ulpian (apparently unique among the classical jurists) contemplated the possibility of iniuria to a slave as the bearer of certain personality rights, despite that slave's continuing legal status as a thing, he could not coherently have admitted the view that there could be a claim for damnum iniuria by a putative master in respect of injury to a person who was not only free but also sui iuris. Once that position was taken up, the question arose whether there was simply no damnum iniuria claim at all in such a case? It is clear that the liber homo

38 D. 41,1,54 (Pomponius 31 Quint. Muc.): Quidquid tamen liber homo vel alienus quive bona fide nobis servit non adquirit nobis, id vel sibi liber vel alienus servus domino suo adquiret: excepto eo quod vix est, ut liber homo possidendo usucapere possit, quia nec possidere intellegitur, qui ipse possideretur...

39 Cf. Wittmann (Fn. 20) 77.

40 Cf. Wittmann (Fn. 20) 104: only the factual subordination of the liber homo bona fide serviens was taken into account, without his being treated as a thing.

41 Cf. again Wittmann (Fn. 20) 104, comparing the position of the liber homo bona fide serviens for the purposes of an Aquilian claim with his status in other contexts, e. g. as object of a sale.

42 E.g. D. 47,10,9,4 (Ulpian. 56 ed.) and the sustained analysis of assaults on slaves at D. $47,10,15,34$ ff. (Ulpian. 57 ed.). According to Ulpian in D. 47,10,15,48, where a liber homo bona fide serviens was beaten, his putative master could sue provided that the beating had been administered in order to insult him, the master. Similarly, in the case of the servus qui aliquem bona fide servit, the bona fide possessor had an actio iniuriarum only if the slave had been beaten in order to insult him; otherwise, only the true dominus could sue, and here only servi nomine on behalf of his slave. The natural inference is that where the beating had not been intended to insult the putative master of a liber homo, the actio iniuriarum accrued to him the liber homo alone. See generallyT.Honoré, Ulpian, pioneer of human rights, 2nded., Oxford 2002, 86-89 and re. Ulpian's analysis of servi verberatio in particular, H. Scott, Contumelia and the South African law of defamation, in: E. Descheemaeker/H. Scott, Iniuria and the 
FINAL PRE-PUBLICATION VERSION June 2014 common law, Oxford 2013, 119, 136-38. 


\section{FINAL PRE-PUBLICATION VERSION June 2014}

would have been entitled to the actio iniuriarum, at least where his injury had been deliberately inflicted ${ }^{43}$, but that left the inadvertent wounding of the apparent slave wholly unpunished. This must have seemed an unattractive solution. Instead, the claim that might have accrued to his putative master was awarded to the liber homo himself. Indeed, he was only personto whom the claim could coherently be allocated. Yet it was awarded essentially by default. Again, it arose from the factual subordination of the liber homo to his putative dominus. Thus the sentence which now begins 13 pr., the focus of Wittmann's analysis, appears originally to have been only the corollary of Ulpian's primary conclusion regarding the claim of his putative master ${ }^{44}$.

At this point we should remind ourselves of the second half of the first sentence of 13 pr., dismissed by Wittmann and others as a gloss ${ }^{45}$ : directam enim non habet, quoniam dominus membrorum suorum nemo videtur $^{46}$. In the first instance this is clearly intended as an explanation for the granting to the liber homo of an actio utilis rather than actio legis Aquiliae. But on closer examination it seems that the use of the word dominus in particular might have a wider significance, and might be intended to bear on the requirement that the claimant be dominus or erus of the thing damaged in order to sue. The sense of the line then becomes not that no one owns his own limbs, but rather that no one can be the owner of the limbs of a free man, not even himself.

If my hypothesis concerning Ulpian's original focus is sound, it might be possible to advance a tentative reconstruction of the first sentence of 13 pr. as it appeared in Ulpian's own text. We might take as the starting point of this re-construction the first sentence of I. 4,4,6, already discussed above. Again, I. 4,4,6 reads as follows:

43 See e. g. D. 47,10,1,7 (Ulpian. 56 ed.), according to which an actio iniuriarum is granted to a liber homo even if he believes himself to be a slave and again D. 47,10,15,48 (Ulpian. 57 ed.) But cf. also D. 47,10,3,4: Si quis hominem liberum ceciderit, dum putat servum suum, in ea causa est, ne iniuriarum teneatur ("If someone beat a free man, thinking that he is the slave, the position is that he is not liable to the $a^{\circ}$ iniuriarum"). Thus the putative master of a liber homo bona fide serviens was immune to the latter's actio iniuriarum. The general rule is stated in 3.2: Itaque pati quis iniuriam, etiamsi non sentiat, potest, facere nemo, nisi qui scit se iniuriam facere, etiamsi nesciat cui faciat ("Thus someone can suffer an insult, even though unaware, but no one can perpetrate one without knowing that he commits an insult, even though he does not know to whom he is doing it").

44 Cf. Wittmann's explanation for this claim, that inasmuch as the liber homo had been so far treated as a slave it would have been inequitable towithhold the specific protection affordeda slave from him: Wittmann (Fn. 20) 104.

45 E.g. Wittmann (Fn. 20) 82. But cf. Feenstra (Fn. 22) 147.

46 "... he has no direct action, because no one seems to be the owner of his own limbs". 


\section{FINAL PRE-PUBLICATION VERSION June 2014}

Sed si libero, qui tibi bona fide servit, iniuria facta sit, nulla tibi actio dabitur, sed suo nomine is experiri poterit: nisi in contumeliam tuam pulsatus sit, tunc enim competit et tibi iniuriarum actio ${ }^{47} \ldots$

Of course, that text requires amendment in order to fit our context: here D. 9,2,11,7-8 constitutes a useful source. Again, that reads:

7. Si in eo homine, quem tibi redhibiturus essem, damnum iniuria datum esset, Iulianus ait legis Aquiliae actionem mihi competere meque, cum coepero redhibere, tibi restituturum. 8. Sed si servus bona fide alicui serviat, an ei competit Aquiliae actio? Et magis in factum actio erit danda.

We must take account also of 13,1 . This reads:

1. Iulianus scribit, si homo liber bona fide mihi serviat, ipsum lege Aquilia mihi teneri.

In light of these fragments, it is suggested that the Ulpianic text which survives in part in the first sentence of $13 \mathrm{pr}$. might originally have read something like:

Si in libero, qui bona fide mihi servit, damnum iniuria datum sit, nulla mihi actio dabitur, sed suo nomine utilem Aquiliae habet actionem: directam enim non habet, quoniam dominus membrorum suorum nemo videtur ${ }^{48}$.

There are a number of further points to be made in favour of this emendation. First, the second and third sentences of 13 make much better sense if understood as responses or qualifications to the primary claim that the bona fide possessor of a liber homo could not sue for Aquilian damages. Regarding the second sentence of 13 pr., here we seem to be reassured that whereas the bona fide possessor of a liber homo bona fide serviens (a free man who looks like a slave) cannot sue, in the case of a slave who is behaving like a free man (a fugitive), the ordinary rule set out in 11,6 holds: his master sues domini nomine. Regarding 13,1, here we are told that while the bona fide possessor of a liber homo cannot sue if the latter is injured, this does not mean that a bona fide possessor cannot sue such a liber homo should he do damage to his (the bona fide possessor's) property ${ }^{49}$.

47 This text appears to be an amalgam of two distinct passages in Digest 47,10 , namely 1,7 (drawn from Ulpian. 56 ed.) - Labeo scribit, si quis servum hereditarium testamento manumissum ante aditam hereditatem verberaverit, iniuriarum heredem agere posse: at si post aditam hereditatem verberatus sit, sive scit se liberum sive ignorat, ipsum agere posse-and the first sentence of 15,48 - Item, si liberum hominem, qui mihi bona fide serviebat, quis ceciderit, distinguendum est, ut, si in contumeliam pulsatus sit, competat mihi iniuriarum actio ...

48 "But if wrongful damage has been done to a free manwho is bonafide serving me, no action is givento me, but he can sue in his own name [suo nomine]: he has no direct action, because no one seems to be the owner of his own limbs".

49 Cf. D. 41,1,54,2: Sed damnum dando damni iniuriae tenetur, ut tamen culpam in damno dando exigere debeamus graviorem nec tamen levem quam ab extraneo ("And by causing 


\section{FINAL PRE-PUBLICATION VERSION June 2014}

However, a still stronger argument arises from closer consideration of the context of another text concerning injuries to a free person, namely the case of the freeborn boy wounded by the shoemaker to whom he was apprenticed discussed by Ulpian in D. 9,2,5,3 and 7 pr. As we have seen, the putative owner's mistake as to the liber homo's status (that is, his belief that the liber homo was a slave) made him a legitimate object of consideration in the context of Ulpian's commentary on erus, as it did the bona fide possessor of another's slave discussed in 11,8. But we can infer that Ulpian did not regard the claim of the liber homo bona fide serviens in respect of his own injuries as an erus issue from the fact that he did not discuss under the heading of erus the case of the freeborn boy and the shoemaker, preferring instead to tack his discussion of it on to the end of his commentary on the word iniuria in the context of Chapter I, which survives in 5, 3 and $7 \mathrm{pr}^{50}$. At first sight this is surprising. As we saw in section 3 above, the relationship between paterfamilias and filiusfamilias seems closely analogous to that of an erus and his res. Indeed, the analogy here seems to be closer than in the case of the bona fide possessor suing in respect of injuries to his putative slave, since the filius was in fact legally subordinate to his paterfamilias. Yet the context in which Ulpian chose to discuss the shoemaker case suggests that he did not see things in this way. It was the putative owner's mistake about the status of the liber homo which brought that case under the erus rubric; in a case where the victim's free status was patent from the start, the erus analogy was excluded.

In fact, the issue with which Ulpian was concerned in 5,3 and $7 \mathrm{pr}$. appears to have been a different one. Once rumpere in the context of Chapter III was understood as corrumpere, it was no longer required that the physical integrity of the thing at issue had been infringed: it was enough, for example, that the defendant had mixed the claimant's corn with sand, so that it was difficult to separate (D. 9,2,27,20). Equally if the defendant sowed tares or wild oats in the claimant's wheat-crop in such a way that it was a nuisance to sort (D.9,2,27,14), an action in factum would arise at least. The damages in such a case were presumably calculated according to the cost of separation, rather than the value of the wheat or corn, since the latter was still intact. Furthermore, in the course of the same analysis (i.e. of rumper ${ }^{51}$ ) atD.9,2,27,17 Ulpian says:

damage, he [the liber homo bona fide serviens] will be liable to us for damage wrongfully inflicted; but we should not require of him in the matter of causing damage the slight degree of fault that would suffice in the case of a stranger but rather gross negligence").

50 Lenel (Fn. 8) $522-523$.

51 See Lenel (Fn. 8) 529 - 530; Rodger (Fn. 9) 176 - 177. 


\section{FINAL PRE-PUBLICATION VERSION June 2014}

Rupisse eum utique accipiemus, qui vulneraverit, vel virgis vel loris vel pugnis cecidit, vel telo vel quo alio, ut scinderet alicui corpus, vel tumorem fecerit, sed ita demum, si damnum iniuria datum est: ceterum si nullo servum pretio viliorem deterioremve fecerit, Aquilia cessat iniuriarumque erit agendum dumtaxat: Aquilia enim eas ruptiones, quae damna dant, persequitur. Ergo etsi pretio quidem non sit deterior servus factus, verum sumptus in salutem eius et sanitatem facti sunt, in haec mihi videri damnum datum: atque ideoque lege Aquilia agi posse.

Particularly significant here is the last sentence of this text, according to which, "if a slave has not been rendered worse in point of his value, but expense is incurred in making him fit and healthy, it seems to me that in this respect loss has been caused [damnum datum], and accordingly it is possible to proceed under the lex Aquilia." Together with texts such as 27,14 and 27,20 , it suggests that the link between actionable damnum (loss) and the (permament) impairment of the physical integrity of a res had been broken, at least in the context of Chapter III. Thus it should not surprise us that Ulpian was prepared to grant a claim for lost earnings and medical expenses on facts such as those described in D. 9,2,5,3. However, this innovation ${ }^{52}$ turned not on the status of the paterfamilias as near-erus but on the fact that loss, damnum, had been caused to him as the result of an injury closely analogous to the rumpere of a slave, i. e. the rumpere of his filiusfamilias: this is why the calculation of that loss features so prominently in $7 \mathrm{pr}$. Put differently, the status of the claimant as erus or near-erus of a damaged thing was no longer necessary to a damnum iniuria claim. Nevertheless, only this subset of cases (i. e. cases in which the clairnant could be said to be "like an owner") was discussed in the context of the erus portion of Ulpian's commentary.

This point - the segregation of the erus question from the question of damnum in Ulpian's edictal commentary - is further underscored by the fact that in the case envisaged in 13 pr. it was his putative owner rather than the liber homo himself who had suffered loss. As a putative slave, the liber homo had presumably not paid his own medical expenses, or suffered the financial consequences of his recovery period ${ }^{53}$. Indeed, had it been discussed in the same light as the case of the shoemaker's apprentice in 5,3, the absence of loss suffered would perhaps have been fatal to the claim of the liber homo; conversely, the loss suffered by the putative owner would have militated strongly in favour of his

52 Julian may have taken a different view: see again the final part of D. 9,2,5,3: an ex locato, dubitat [/ulianus], quia levis dumtaxat castigatio concessa est docenti: sed lege Aquilia posse agi non dubito ("Julian wonders whether there is an action for breach of the contract for his services as a teacher, since a teacher only has the right to administer reasonable chastisement, but I have no doubt that action can be brought against him under the lex Aquilia"). But in 7 pr. it appears to be Julian who is speaking (ait). Cf. Fn. 16 above.

53 This depends of course on when the true status of the putative slave came to light. 


\section{FINAL PRE-PUBLICATION VERSION June 2014}

recovery. But as I remarked in section 2 above, the loss suffered by the potential claimant (or the absence thereof) does not appear to have informed Ulpian's reasoning in his commentary on erus. Thus Ulpian was not forced to confront this apparent anomaly in resolving the case of the liber homo bona fide serviens in the way that he did. 
FINAL PRE-PUBLICATION VERSION June 2014 